\title{
REGIONAL DIFFERENTIATION OF COMMODITY TRADE OF UKRAINE WITH POLAND
}

\author{
Volodymyr Lazhnik ${ }^{1}$ (D) - Serhii Puhach ${ }^{2}$ (iD) $\cdot$ Andrii Maister $^{3}$ (D) \\ ${ }^{1}$ Faculty of International Relations \\ Lesia Ukrainka Eastern European National University \\ Volia Avenue, 13, 43000 Lutsk: Ukraine \\ e-mail: lazhnik-vi@ukr.net \\ ${ }^{2}$ Faculty of Geography \\ Lesia Ukrainka Eastern European National University \\ Volia Avenue, 13, 43000 Lutsk: Ukraine \\ e-mail: puhachserhiy@gmail.com (corresponding author) \\ ${ }^{3}$ Open International University of Human Development "Ukraine" \\ Heorhii Honhadze Street, 5, 43020 Lutsk: Ukraine \\ e-mail: maister89@ukr.net
}

\begin{abstract}
The purpose of this article is to examine the status of the Ukrainian-Polish bilateral trade links, to identify regional characteristics and disparities in the Ukrainian commodity trade with Poland. The place of Poland in the geographical structure of commodity exports and imports with regard to Ukrainian regions has been studied. Balance and connectivity coefficients of commodity trade with Poland have been calculated for 25 regions of Ukraine. Regionally influenced differentiations between the Ukrainian and Polish regional commodity trade links have been revealed. The groups of Ukrainian regions have been determined on the basis of the level of their commodity trade balance and type of external trade links with Poland.
\end{abstract}

\section{Key words}

export - import $\cdot$ commodity trade $\cdot$ trade balance coefficient $\cdot$ trade connectivity coefficient $\cdot$ transport linkages $\cdot$ Ukraine $\cdot$ Poland

\section{Introduction}

The issue of expanding external trade links, especially with neighbouring countries that are the EU members, is gaining importance at the present stage of Ukraine's development in the context of the declaration of its European integration aspirations after signing the Association Agreement with the EU in 2014. Poland is of particular importance for Ukraine, as it is a direct neighbour and a strategically important trading partner that has long-term 
external trade links with Ukraine and actively supports Ukraine's European integration aspirations. All the regions of Ukraine have established stable trade links with merchandising companies and its partners in Poland. Therefore, the urgent task is to carry out a spatial analysis of regionally influenced differentiations and to identify the commodity trade degree of connectivity of Ukrainian regions with its partners in Poland.

Development of external trade changes today is characterized by its geographical and commodity structure transformation under the influence of the globalization and regionalization processes, given the absolute and relative advantages of the country or region in terms of commodity production. Traditionally, the external trade has been approached, in geographical research, primarily from a theoretical perspective, within the theoretical context of the labour trade international division. The external trade development current trends have led to the application of new theoretical models based on the combination of location and international trade theories from the perspective of a new economic geography. The main reason for external trade interactions between countries and regions is the presence of production factors determining the nature and share of offers on the world market and the production specialization in domestic and international labour division systems. These factors lead to the external trade regional differences. Therefore, it is important to analyze the geographical features of the external commodity and service trade at various spatial levels.

Owing to a long history of development, the Ukrainian-Polish interstate relations have been of a dynamic nature. Poland recognized the independence of Ukraine on December 2, 1991 and established diplomatic relations with it on January 8, 1992. The legal framework between Ukraine and Poland totals more than 50 interstate documents regulating the external trade links between the two countries. Among them are important documents such as the Treaty of Good Neighbourhood, Friendly Relations and Cooperation between
Ukraine and Poland dated back to May 18, 1992 (Agreement... 1992), the Agreement between the Government of Ukraine and the Government of Poland on Trade and Economic Cooperation dated October 4, 1991 (Agreement... 1991) and a number of other documents.

The EU-Ukraine Association Agreement, signed in 2014 and entered into force on September 1, 2017, is very essential for the development of Ukrainian-Polish bilateral relations. It envisages the establishment of conditions conducive to the formation of an in-depth and comprehensive free trade zone between Ukraine and the EU, a member of which is Poland. In the field of bilateral trade and economic cooperation, a coordinating role is given to the Intergovernmental Commission on Economic Cooperation, founded in 2006, within which a working group on trade and investment has been currently operating. In November 2006, its first meeting was held. The last (sixth) meeting of this Commission was held on April 20-21, 2017 in Warsaw (Poland 2019).

Since Ukraine gained independence in December 1991, external trade links between the two countries have been constantly expanding, although their dynamics have been unstable, especially in the past 10 years, for various reasons and circumstances. Both the dynamics and intensity of Ukrainian-Polish relations over the past decades have been determined by historical, geopolitical, socio-economic and political-geographical prerequisites and factors for establishing interstate relations. Poland has always been one of the Ukraine's most important strategic and trading partners (Współpraca... 2020).

The revival of the Ukrainian-Polish bilateral trade cooperation in recent years is associated with the liberalization of the external trade between Ukraine and the EU. Additionally, it coincides with the establishment of trade links between commercial and business structures of the two countries, investment and production cooperation, and the expansion of the cross-border and interregional cooperation in accordance with 
the provisions establishing a deep and comprehensive free trade area. Ukraine today has the most developed network of the interregional cooperation with Poland, positively resulting in the development of their bilateral trade. Almost all the regions of Ukraine and the voivodeships of Poland concluded agreements on the interregional cooperation. Most of the Polish partners are Ukrainian regions: Lviv, Odesa, Ivano-Frankivsk, Volyn and Vinnytsia. Subcarpathian, Lublin, Łódź, Silesian and Masovian voivodeships are those Polish voivodeships that have more Ukrainian partner regions than others (Popova, Radchenko, \& Yakushenko, 2016).

Despite the positive dynamics of trade links, a noticeable asymmetry is observed in Ukrainian-Polish trade relations. While Poland is one of the main trade partners for Ukraine, Ukraine is not among the leading countries in the Polish external trade. Poland's external trade is oriented towards the EU and developed countries. As of 2018, Poland was the second largest trading partner of Ukraine in the EU (with a specific gravity of $14.7 \%$ ), as well as the fourth trading partner in the world (with a specific gravity of $6.2 \%$ ) in terms of export-import operations after the Russian Federation, China and Germany (Współpraca ... 2020). In 2018, Poland ranked the second among the countries of the world after the Russian Federation (7\% of Ukrainian global exports and 16.2\% of Ukrainian exports to the EU) in the geographical structure of Ukrainian commodity exports. As regards the geographical structure of commodity imports, Poland ranked the fifth in 2018 (External... 2019). According to the State Statistics Service of Ukraine, the trend towards an increase in bilateral trade with Poland continued in 2019. In the first half of 2019, Poland came out in the 1st place in the geographical structure of Ukrainian exports and the 4th place in the geographical structure of Ukrainian imports. A similar situation existed in trade in services, where Poland's share in Ukrainian exports and imports of services was slightly lower and amounted to $3.0 \%$ (the 6th place among world countries) and 3.1\% (the 9-th place accordingly) (External... 2019).

At the same time, Ukraine was for Poland one of the key partners among the countries of the entire post-Soviet space, and the second only to the Russian Federation. Ukraine was in the 15th place among the largest importers of Polish goods (2.02\% of the total) in 2018. In terms of export of Polish goods, Ukraine was in the 20th place (with a share of $1.13 \%$ ) among other world countries. Simultaneously, Ukraine was in the 7th place among the countries; with the largest positive balance for Poland - more than 2.1 billion USD in the bilateral commodity trade (Współpraca... 2020).

\section{Literature review}

Works of scholarly research, written by Krugman (1991), Fujita, Krugman and Venables (1999), Tinbergen (1962), Anderson and Wincoop (2003), Porter (1998), just to name a few, are considered important for studying international trade theory and for the formation of a "new economic geography". So, Krugman (1991), Fujita et al. (1999) perceive the new economic geography model as the tool combining elements of traditional regional science and new trade theory. It has been designed for the analysis of the geospatial structure peculiarities and of the degree of concentration and differentiation of country and regions' external trade links.

Simultaneously, Aguirre (1999), Dickson (2014), Linetsky, Tarasov, and Kovalev (2017), Royles (2017), Zhiryaeva (2016) and so forth assessed trade links among regions and subnational units based on the new economic geography conceptual provisions. Their studies looked at the factors that determine present-day external (trade) ties between the world countries and the regions, as well as examining commodity flows and regional differentiations at the interstate level, both in commodity and geographical structure and in terms of shares.

The application of theoretical ideas proposed by Krugman (1991) allows us to prove 
that the dominance of large cities and the industrialized regions of the country in production characterize the geographical structure of countries' external trade. This leads to regional disproportions and differences in the distribution of external and internal trade factor flows, which have become important objects of the geographical research in order to identify the features and directions of the geographical structure of external trade transformation.

Gravitational models of trade interactions among countries and regions within the framework of the new economic geography, proposed by Tinbergen (1962), Anderson and Wincoop (2003), McCallum (1995) and others, make possible to assess bilateral trade flows among countries and regions, considering the gross regional product of two countries or regions and the distances between them. Porter (1998) attempted to combine neoclassical competitiveness theories with the theory of external economic activity of individual regions and firms within the country. According to Porter's theory of competitiveness, the spatial structure of external trade is significantly differentiated due to intense competition on the domestic market of a country, which determines the level of its regional participation in the external trade, depending on the availability of competitive advantages.

The classical theory of international trade states that in the context of increasing globalization, modern foreign trade relations are liberal in nature through the intensification of transnational corporations (TNCs) and the internationalization of production, which spreads in the form of horizontal and vertical specialization in foreign trade. As Hummels, Rapoport and Yi (1998) point out, vertical specialization is formed when a country uses imported intermediate goods and services for further production of export goods. This concept is based on the idea of establishing consistent global ties between countries for the production of final goods. According to many scholars, the assertive role of global connections is manifested in the fact that in the process of interaction the participants in world economic relations form global production chains of new value creation and network structures at the level of firms, TNCs, regions and states. Scientists such as Coe, Dicken and Hess (2008), Kaplinsky and Morris (2003), Dicken, Kelly, Olds, and Yeung (2001), Mahutga (2014), Parrilli, Nadvi and Yeung (2013), Peck (2003) and others made important contribution to the development of theories of global connections, chains creating new value, and global production networks. According to Dicken (2015), the modern global economy is transformed by the means of operation of global production networks with the participation of TNCs, states as well as stakeholders and technologies. P. Dicken, studying the geographical features of the global economy, investigated the structure and dynamics of global production networks, described the role of TNCs in the world economy and trade and explained why they are a barometer of global economic change and determine the direction of modern international trade flows (Dicken, 2015). P. Dicken showed how global production chains form new value chains and network structures and relationships between TNCs and nations.

Therefore, studies of external trade are becoming increasingly relevant from the perspective of a regional approach allowing us to assess the rationality of its geographical structure, since the prospects of external trade links are directly related to the economic restructuring of national economies in the context of globalization and supranational regionalization (primarily with the EU). The focus of research are the spatial features of the concentration and differentiation of external trade links among individual countries and their regions, identified under their territorial or organizational nature.

The scientific literature survey concerning the issues surrounding Ukrainian-Polish ties indicates a significant interest of both Ukrainian and Polish researchers in studying the Ukrainian-Polish problems in bilateral cooperation over various fields. Dominant 
research topics have become the basis of Ukrainian-Polish bilateral relations in the economic sphere and interstate political contacts that have been raised in many publications, mainly with an emphasis on identifying the dynamics and patterns of commodity and service exports and imports at the interstate level, challenges and opportunities of the bilateral economic and cross-border cooperation. However, the issues revealing the spatial features of bilateral trade links at the regional level have been poorly covered.

The analysis of the Ukrainian-Polish trade and economic cooperation at the interstate level over the past decades, as well as key aspects of their cooperation in the light of the European integration processes and the participation of both states in these processes have been dominant in the Ukrainian scientific literature. Articles by Chorna (2016), and by Martynova and Chorna (2018), are devoted to the analysis of main areas of the trade and economic cooperation between the two countries during 2004-2016 period, the dynamics of its main indicators and the specifics of the commodity structure of trade flows. The state and prospects of the external trade between Poland and Ukraine for the period from 2007 up to 2014 in the context of identifying common trends in the development of external trade transactions are reflected on in the article written by Raboszuk \& Szymańska (2016). In other publications of Ukrainian scientists, the main areas of cooperation on an inter-regional and the state basis, as well as main trends and prospects for the development of trade links between the border territories of Ukraine and Poland are examined within the framework of the Carpathian Euroregion and the Euroregion "Bug" (Osadcha \& Petrova, 2017; Popova et al., 2016, and so on). Babets, Borshchevsky and Mihushchenko (2011) reflected upon parameters of the external economic activity asymmetry in the Ukrainian-Polish cooperation for 2010, as well as the disproportionality of the commodity exchange in the interregional cooperation of Ukraine's regions and the Poland's voivodships.
Many scientists, among them L. Aleksiievets, M. Aleksiievets and Ilchuk (2015), Borshchevsky (2007, 2009), Duhiienko and Shevchuk (2017), Korchun (2013), Makar (2016), Mazaraki and Melnyk (2010), Zelich and Titarenko (2016), studied various aspects of Ukrainian-Polish trade and economic ties. However, despite a large number of scattered scientific publications, the comprehensive economic and geographical studies on the problems of geospatial analysis of Ukrainian-Polish trade ties in Ukrainian geographic scientific domain have not been thoroughly studied yet.

The topic of Ukrainian-Polish interstate trade and economic cooperation for both Polish and international researchers has not become a priority and as of yet has a limited view of Ukraine. Polish researchers mainly analyze the conceptual foundations of Ukrainian-Polish interstate ties in the political sphere, while the trade and economic sphere is still not sufficiently considered. External trade ties between the two countries are mainly considered in the context of interstate cooperation and strategic partnership from the standpoint of analyzing the dynamics of commodity and service trade, identifying the characteristics of the commodity structure of trade, cooperation challenges and opportunities. At the same time, geospatial aspects of Ukrainian-Polish trade links have not been sufficiently analyzed.

Articles written by Ambroziak and Błaszczuk-Zawiła (2016), Baluk (2018), Wosiek and Kata (2019), Komornicki (2009a, 2009b, 2010), Kalita (2008), Kalita, Puchalska, Barwińska-Małajowicz (2007), Powęska (2016), Jakimowicz (2004) are notable among Polish scientific publications addressing the certain issues of Polish-Ukrainian trade ties. Thus, Baluk (2018), considering the formal and material dimensions of the strategic partnership between Poland and Ukraine, focuses on the economic dimensions of employees' quality along with political dimensions, and analyzes the share of the Ukrainian-Polish external trade for the period from 2010 up to 2014. Baluk points to a significant increase 
in the bilateral trade, indicating that Poland is one of Ukraine's main trading partners. Kalita, Pukhalska and Barwińska-Małajowicz (2008) analyzed the share of Polish-Ukrainian bilateral commodity trade, its dynamics and structure for the period from 1992 up to 2006. Moreover, they found out the trade importance in the cross-border cooperation among the Polish and Ukrainian border regions.

Particularly noteworthy are works written by Komornicki $(2009 a, b, 2010)$ and others, where a regional approach was applied to the analysis of external trade in the context of the Poland's regional policy objectives. In particular, Komornicki (2010), based on a regional approach, analyzes the role of commodity trade with the border regions of the eastern neighbouring countries, including Ukraine, in the development of economy of Poland's voivodeships and counties. Komornicki focuses on the uniqueness of commodity trade with neighbouring Ukrainian regions for the socio-economic development of the Lublin and Subcarpathian voivodeships.

The spatial analysis of trade links was carried out in the works of other Polish scientists too. In particular, Szejgiec and Komornicki (2015) provided a spatial analysis of Poland's export ties with foreign countries, where a certain attention was given to Ukraine (CIS countries). Based on a regional approach and within the context of Ukrainian-Polish relations, Musiałowicz (2017) analyzed changes in the share of merchandise exports and imports of the Ukraine's regions, as well as in trade relations with Poland as of 2016 in comparison to 2015. Moreover, Musiałowicz determined the place of Poland in the external trade of Ukraine's regions.

Thus, the analysis of scientific publications on the subject of Ukrainian-Polish trade links reveals the proper national level of trade links between Ukraine and Poland. However, at the regional level, this issue, from the viewpoint of economic geography, has not been adequately studied in both Ukrainian and Polish scientific literature. The geographical aspects of bilateral trade links and their regional differentiation and concentration have been, as yet, insufficiently analyzed. For that reason, it has been an urgent task to analyze the commodity trade between the Ukraine and Poland's regions (within a regional approach) from the socio-geographical point of view. These above mentioned considerations have led to the choice of the topic of our study.

\section{Materials and methods}

The statistical data for the period from 2001 up to 2018, released by the State Statistics Service of Ukraine, were used to analyze the Ukrainian-Polish trade links and to determine the main trends in their development. In particular, to identify the features of spatial differentiation of the regional distribution of these relations, the official data of regional statistical departments of the Ukrainian 24 regions and the city of Kyiv have been used, posted on the websites of these departments in the section "Geographical structure of foreign trade in goods" (Area... 2019). The following basic indicators were analyzed in this article: volumes of export and import, foreign trade turnover and balance of commodity trade between Ukrainian regions and Poland in 2018. At the same time, statistics on the territories of the Autonomous Republic of Crimea and the city of Sevastopol, those parts of the Luhansk and Donetsk regions, as well as other regions that are not controlled by Ukraine, have been left out. Additionally, the Ukrainian-Polish trade in services has been not included in the current paper, since, interstate trade operations account for 7.3\% of their total volume (according to the State Statistics Service of Ukraine). In 2018, trade in services between Ukraine and Poland was only 546.3 million USD (State... 2019). Hence, interstate trade in services within the regional context requires a separate detailed study.

In order to conduct the analysis of the regional differentiation of commodity trade between Ukraine and Poland, a selection of statistical indicators and procedures 
for their interpretation have been prepared. At the initial stage, the Ukrainian-Polish external commodity trade dynamics, covering the period 2001-2018, has been analyzed, as well as determining its contemporary product structure and the growth rate of exports, imports, balance and external trade by use of statistical regression and correlation analyses. We have used a probabilistic polynomial model to find the dependent variables in the dynamics of commodity trade indicators by the following formula:

$$
y_{i}=b_{0}+b_{1} x+b_{2} x^{2}+b_{3} x^{3}+b_{4} x^{4}
$$

Unknown parameters like $b_{0}, b_{1}, b_{2}, b_{3^{\prime}}$ $b_{4}$, characterizing certain groups of factors, affecting the commodity trade have been calculated using the least square method. Any verification of the expository power of the polynomial model, chosen herein, allows explaining the specific dynamics of trade flows and the general axes in this dynamics under study. Additionally, the correlation analysis technique has been employed to show the reliance of the share of trade flows on the volume of the regional gross product produced and to test the expository power of the regression model in its entirety. To test the statistical significance of the correlation coefficients, Student's criterion (t-test) was used.

An important external trade factor is reflected in a balance coefficient revealing the ratio of export and import flows among the regions of Ukraine. It is calculated as the ratio of the external trade balance to the total trade turnover by the following formula:

$$
K z b_{i}=S_{i} / T_{i}
$$

where:

$K z b_{i}$ - the balance coefficient of the commodity trade between the $i$-region of Ukraine and Poland;

$S_{i} \quad$ - the balance of commodity trade of a region of Ukraine with Poland;

$T_{i}$ - the volume of external commodity trade turnover of the $i$-th region with Poland.

The value of the $K z b$, balance coefficient of the commodity trade can range from 1 to -1 . The positive value reflects the greater volume of exports than imports, the negative value shows the greater volume of imports than exports, and 0 (zero) reflects the equality of exports and imports.

The trade influence or trade and economic connectivity coefficients are very often used in geographical studies to measure the complementarity of trade links. They are calculated as the ratio value of the mutual trade turnover volume to the total GDP of interacting countries or regions. However, these coefficients do not adequately reflect the regional differentiation of trade links. For a regional external commodity trade analysis, it is more advisable to apply a methodology that is based on the criteria for the connectivity and symmetry of trade links. In our study, the trade connectivity coefficient $(K z v)$, whose calculation algorithm was proposed by Vaniushkin (2004), has been used. It is more correct, since it takes into account the ratio of the share of exports and imports of a region in a particular country in the total volumes of exports and imports of the studied region. We calculated this coefficient using the formula (3):

$$
K z V=\left(X_{m n} / X_{m}\right):\left(M_{n m} / M_{m}\right)
$$

where:

$K z V$ - means the trade connectivity coefficient of the $m$-region with the $n$-country;

$X_{\mathrm{mn}}$ - exports from the $m$-region to the $n$-country;

$X_{m}$ - the aggregate exports of the $m$-region;

$M_{n m}$ - imports from the $n$-country to the m-region; $M_{m}$ - the total imports of the $m$-region.

If there is an asymmetry in the bilateral commodity trade, various versions of the connectivity coefficient $K z v$ are possible, which indicate a certain degree of dependence of each region on country $n$ (in our case, Poland) both in commodity export and import. The trade connectivity coefficient $K z V$, which is equal to or greater than one, indicates the trade connectivity in region $m$ with country $n$ (in our case, Poland) and a high degree of focus on trade links with trading partners in country $n$. When the coefficient is less than one, three cases are possible due 
to the imbalance in trade among the studied regions and the partner country (Matveeva, 2007).

In the first case, the share of exports from the $m$-region to the $n$-country is much greater than the average volume of its exports to all of the countries with which it trades. Then, such a region depends upon the $n$-importer, but there is no feedback due to the significant size of the $n$-country's market. In a formalized form, it looks as follows:

$$
X_{\mathrm{mn}}>X_{\mathrm{m}} / N_{\mathrm{xm}}
$$

where:

$N_{\mathrm{xm}}$ - means the number of those countries to which the $m$-region exports goods.

In the second case, the n-country's share in the $m$-region exports is much smaller than the $m$-region share in the $n$-country's imports. Then, the $n$-country depends on the exports of the $m$-region, but the $m$-region does not depend upon the trade with the n-country. In a formalized form, it looks like:

$$
\left(X_{m n} / X_{m}\right)<<\left(M_{n m} / M_{n}\right)
$$

where:

$M_{n}$ - means the $n$-country's aggregate import.

In the third case, the exports from the $m$-region to the $n$-country are less than the average volume of its exports to all the partner-countries, and imports from the $m$-region to the $n$-country are less than the average volume of the n-country's imports from all of the trading partner countries. This shows the independence of the $m$-region and the $n$-partner-country from each other in the commodity trade. In a formalized form, it looks like:

$$
X_{m n}<\left(X_{m} / N_{x m}\right) \text { i } M_{n m}<\left(M_{n} / N_{m n}\right)
$$

where:

$N_{m n}$ - means the number of countries from which the $n$-country imports goods.

Computational results, concerning the connectivity coefficient $(K z v)$ of trade links among the Ukrainian and Polish regions according to the technique mentioned above, allow us to assess the dominant trade flows and the asymmetry of the trade links, as well as to classify regions by the type of their trade links with Poland. To perform calculations, the share of commodity export and import of the Ukrainian regions in bilateral trade with Poland has been used, based on the data of regional statistical offices (State... 2019) and on the data on Poland's external trade since 2018 accessed from the website of the Ministry of Enterprise and Technology of Poland (Ocena... 2019).

\section{The current state of commodity trade between Ukraine and Poland}

The analysis of external trade links between Ukraine and Poland since the beginning of the 21 st century showed that the external commodity trade turnover was increasing systematically before the global economic crisis (2008-2009). According to the State Statistics Service of Ukraine, it amounted to 888.3 million USD in 2001, and reached 6, 618.6 million USD in 2008 (State... 2019). In subsequent years, the bilateral external trade dynamics was unstable. Therefore, in 2009, the share of external trade sharply decreased to 3,383.4 million USD that is by almost 2 times. The trade turnover steadily increased in the following years and amounted to $6,616.5$ million USD in 2013, but there was a recession again in 2014-2015. It was due to the crisis in the Ukrainian economy combined with the Russian military operations in the Crimea and in Donbas. In 2015, total trade turnover with Poland amounted to 4,301.4 million USD. However, in subsequent years, despite such factors as the incomplete processes of reforming the Ukrainian economy, the crisis caused by political instability in Ukraine, the annexation of Crimea and military operations in the East, the trade between the two countries showed an increase in total trade. In 2018, the share of trade between Ukraine and Poland reached 6,899.2 million USD (Fig. 1A), which is the highest indicator for all the years of the Ukrainian-Polish 
trade cooperation (State... 2019). This testifies to the intensification of Ukrainian-Polish trade links, based on the implementation of the provisions of the Association Agreement between Ukraine and the EU, and the dominance of commodity trade between Ukraine and Poland. Thus, Poland has always remained one of the main trading partners of Ukraine throughout the entire period of its existence as an independent state.

Figure 1 shows the trends in the dynamics of such indicators of trade in goods between Ukraine and Poland in 2001-2018 period, as well as the volume of foreign trade, exports, imports and trade balance. The common trend in the dynamics of the UkrainianPolish external trade for the period 20012018 can be described by a fourth-degree polynomial model with a sufficiently high determination coefficient $\left(R^{2}=0.84\right)$ (Fig. 1A). This model reflects the impact on commodity trade of such factors as the volume of produc-
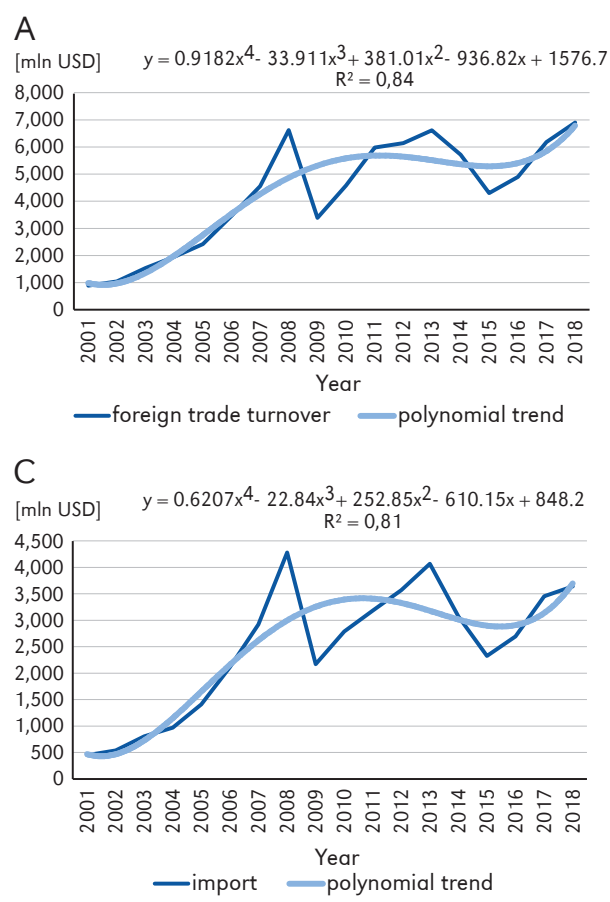

tion of raw materials, industrial and agricultural goods, their value on the world market, the volume of transport, etc. Similar models of the trend, based on the polynomial function, are also traced in the dynamics of volumes of commodity export deliveries from Ukraine to Poland $\left(R^{2}=0.85\right)$ and imports from Poland to Ukraine $\left(R^{2}=0.81\right)$ (Fig. 1B and $1 \mathrm{C}$ ). However, the trend in the commodity turnover balance over an almost 20-year period is characterized by a significantly low determination coefficient $\left(R^{2}=0.56\right)$ (Fig. 1D). This shows the influence of several groups of various factors on trade between the two countries, which led to instability and significant fluctuations in the volume of mutual deliveries of goods, especially in last 10 years.

Since the beginning of the 21st century, the common trend of the Ukrainian-Polish bilateral trade links has coincided with the overall trends of the Ukrainian external

\section{B}

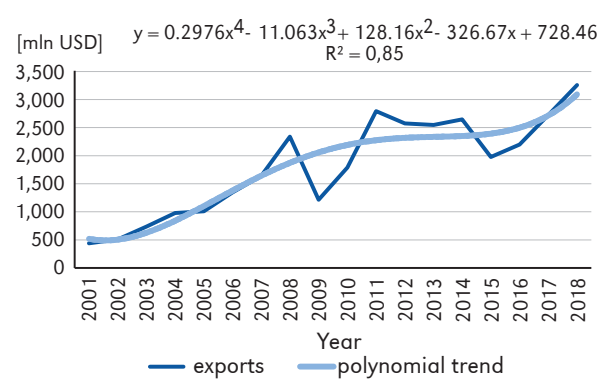

$\mathrm{D}$

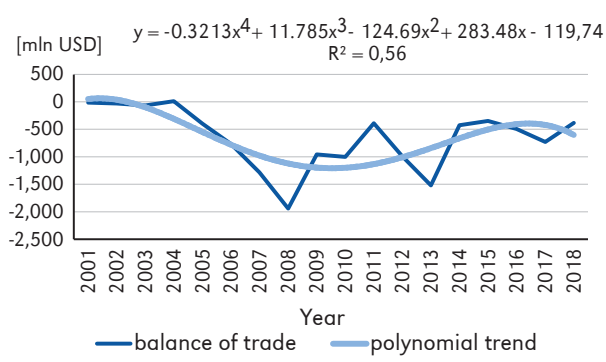

Figure 1. Dynamics of indicators of the Ukrainian-Polish bilateral commodity for the period 2001-2018: A - commodity circulation; B - commodity export; C - commodity import; D - commodity trade balance Source: Based on data from State Statistics Service of Ukraine (2019). 
commodity trade with other countries. Thus, for the 2001-2018 period, the coefficient of pair correlation between the share of commodity exports from Ukraine to other countries and the share of Ukrainian commodity export to Poland amounted to $0.78\left(\mathrm{t}_{\mathrm{st}}=5.06\right.$; $\left.t_{16 ; 0.05}=2.12\right)$ and $0.89\left(t_{s t}=7.37 ; t_{16 ; 0.05}=2.12\right)$ for commodity imports. Therefore, UkrainianPolish trade links, as well as the trade links with other world countries, since the beginning of the 21st century, have had mostly the upward trend, however from time to time with varying degrees of difficulties. Strong positive dynamics in the Ukrainian-Polish commodity trade was seen in the years 2001-2008, 20102012 and 2016-2018 (Fig. 1), whereas there was a significant decline in 2009 due to global economic crisis, and decline in the years 2014-2015 brought about by the fighting in the East of Ukraine.

Commodity export-import operations (2001-2018) between the two countries were characterized as the commodity external trade with a steady negative balance for Ukraine, except for the period of 2004. The worst situation was in 2008, when it reached -1,942.0 million USD (Fig. 1D). In the subsequent years, the negative balance was unstable and in 2013 amounted to $-1,520.9$ million USD. However, later on, the trend tended to be more positive for Ukraine, and in 2018, its negative balance totalled -384.7 million USD (Fig. 1D). This was due to the growth of exports accompanied by a decrease in the growth rate of imports, which became the general trend of Ukraine's external trade after the sociopolitical events of 2013-2014, despite the crisis in the Ukrainian economy.

The structure of the Ukrainian commodity export to Poland in recent years has not undergone significant changes. In particular, in 2018 relative to 2017, there was an increase in exports for many commodity items. The commodity scope of the delivery, consisting of ferrous metal products, mineral fuels, oil and products of its distillation, inorganic chemistry products, vegetables, products of the milling and cereal industry, silk, cotton, railway locomotives and other goods grew significantly. This testifies to the structural expansion of the Ukrainian commodity exports to Poland, and to the involvement of Ukrainian enterprises in the closer cooperation with the Polish ones, resulting in the export structure improvement and its raw material share reduction. Ferrous metals $(14.9 \%$ of the total volume of merchandise exports to Poland), ores, slag, and ash $(11.8 \%)$ dominated in the commodity structure of Ukrainian exports to Poland in 2018. A significant share in the export of Ukrainian commodities to Poland is also occupied by electric machines (11.6\%), wood and wood products $(8.2 \%)$, furniture $(6.9 \%)$, ferrous metal products (3.9\%), fats and oils of animal or vegetable origin (3.9\%) and other products (External... 2019). In total, low value-added commodities dominated in the structure of export deliveries from Ukraine to Poland.

At the same time, as in previous years, technological high value-added commodities with a high diversification level became the largest share of Polish imports to Ukraine in 2018. Key goods imported from Poland to Ukraine in 2018 were as follows: plastics and polymer materials $(8.8 \%$ of the total share of imports of Polish goods to Ukraine), electric machines (8.6\%), mineral fuel, oil and products of its distillation (8,3\%), nuclear reactors, boilers, machinery $(8.2 \%)$, ground transportation means, except for railway $(7.8 \%)$ and other goods (External... 2019). The Polish share of imports, of such goods as copper and copper-based alloy products, nickel and nickel-based alloy products, other base metals, aircraft, ships, alcoholic and non-alcoholic drinks and vinegar and others, significantly increased.

\section{Results and discussion}

A significant spatial differentiation and great variability in the magnitude of trade turnover are present in the geographical structure of external commodity trade among the Ukrainian and Polish regions. Development disproportions in the Ukrainian-Polish interregional cooperation are reflected in a noticeable asymmetry in the external economic 
activity parameters in the Ukraine's economic cooperation with Poland. This is primarily manifested in attracting to the commodity trade exchange mainly western regions and economically highly developed regions of Ukraine, in a negative balance in commodity external trade, in low investment activity, and in an ineffective export structure of Ukrainian regions.

Poland is the largest trading partner and investor for the western regions of Ukraine, while other regions has a significantly lower level of the trade cooperation with Polish partners. Therefore, in 2018, the largest share of commodity trade turnover decreased in the city of Kyiv (1,445.8 million USD), whilst Lviv, Dnipropetrovsk, Kyiv, Ternopil, Donetsk and Volyn regions had slightly smaller shares of commodity turnover with Polish voivodeships. At the same time, the value of exports to Poland from the Dnipropetrovsk region (mainly mining-metallurgical products) was approximately 3.5 times as high as the value of imports from Poland (Fig. 2). Kyiv, in its turn, is the main importer of Polish commodities (Fig. 3), owing to the fact that the Ukrainian capital accounts for more than $31 \%$ of all the Polish commodity imports to Ukraine (External... 2019).

The analysis of statistical data has shown that there is a direct dependence of the turnover between the regions of Ukraine and Poland on their population, because the pair wise correlation coefficient is $0.90\left(\mathrm{t}_{\mathrm{st}}=9.90\right.$; $\left.t_{23 ; 0.05}=2.07\right)$. The largest volumes of trade turnover with Poland per capita of the region in 2018 were in Kyiv (490 USD), Lviv (435 USD), Ternopil (383 USD), Volyn (292 USD) and Dnipropetrovsk regions (286 USD).

In 2018, the smallest share of commodity trade with Poland was in Kirovohrad (20.8 million USD), in Kherson, Chernivtsi, Chernihiv,

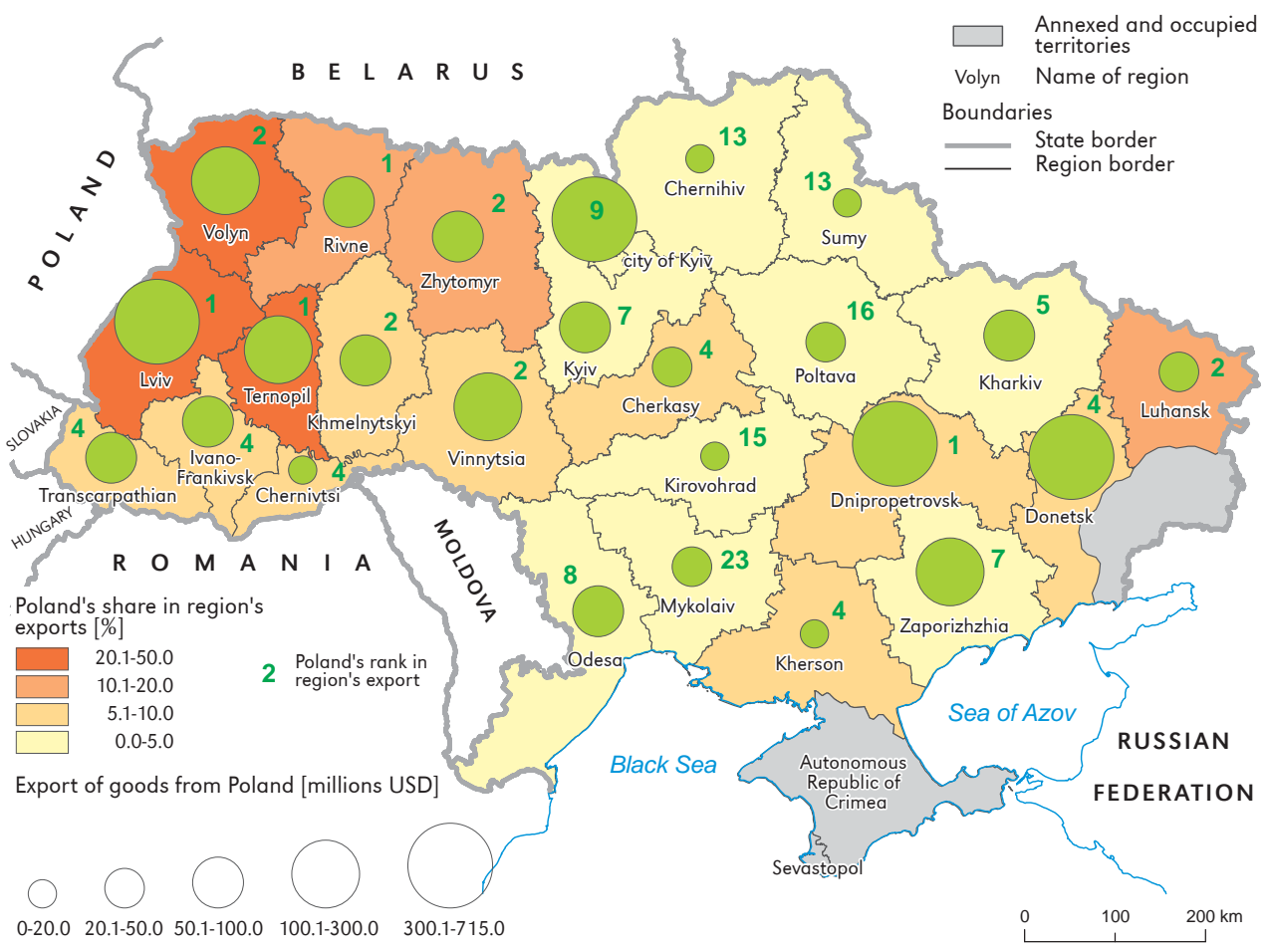

Figure 2. Regional differentiation of exports of Ukrainian goods to Poland in 2018

Source: Based on data from State Statistics Service of Ukraine (2019). 


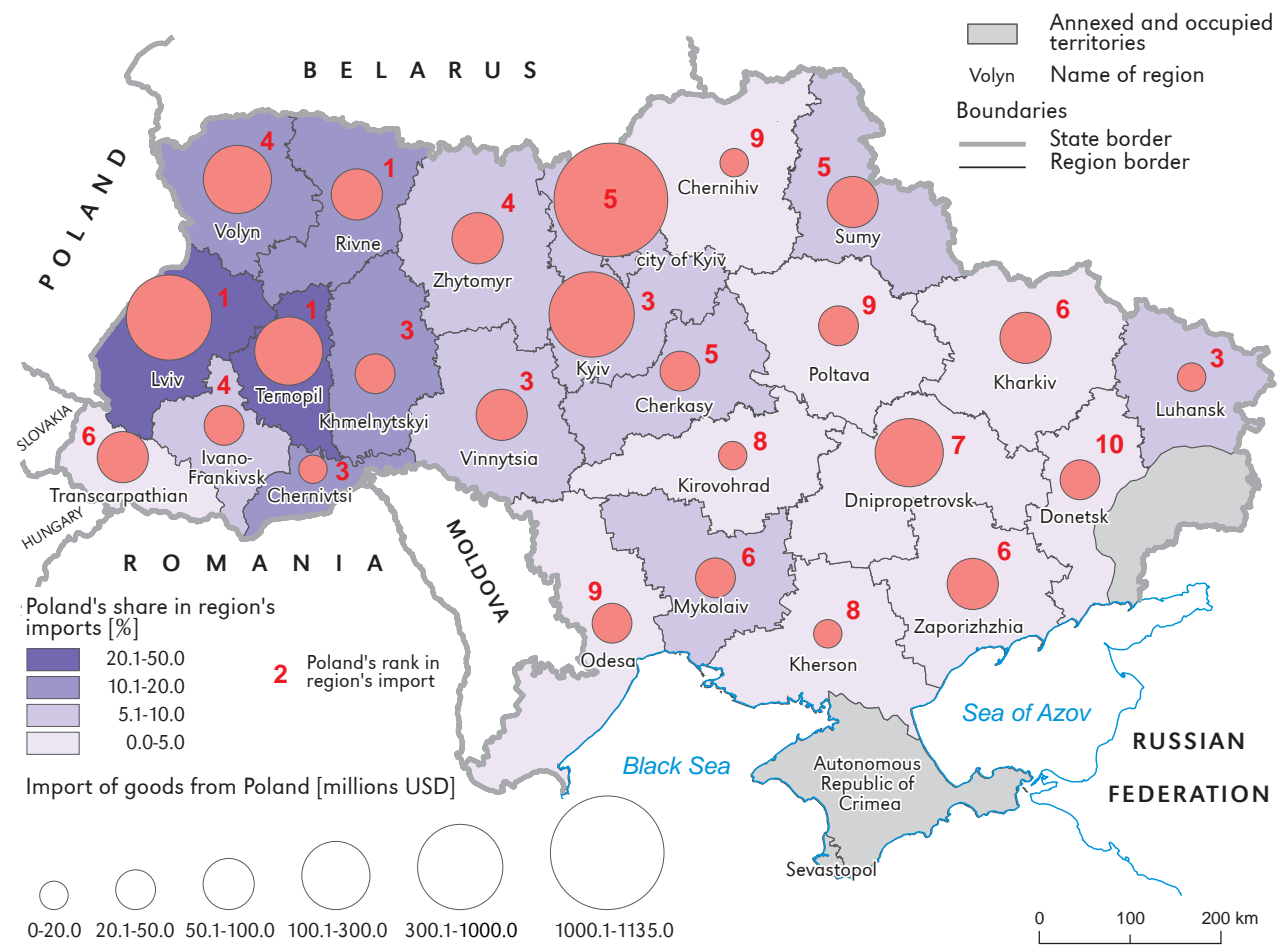

Figure 3. Regional differentiation of imports of goods from Poland to Ukraine in 2018

Source: Based on data from State Statistics Service of Ukraine (2019).

Luhansk, Mykolaiv, Sumy and Poltava regions (Fig. 2 and 3) because of their low socio-economic development level. The same regions are characterized by the smallest volumes of trade per capita (for example, in Luhansk region this indicator is only 17.3 USD).

The Ukrainian-Polish commodity trade turnover is characterized by direct dependence on the share of their gross regional product, since their pair correlation coefficient is $0.82\left(t_{s t}=6.74 ; t_{23 ; 0.05}=2.07\right)$. Thus, in 2018 Kyiv was the leader in terms of gross regional product production (UAH 699 billion) among the regions of Ukraine (State... 2019) and, accordingly, the leader among the regions in terms of trade turnover with Poland (External... 2019). Similar positions are occupied by Dnipropetrovsk, Kyiv and Lviv regions. The exceptions are Ternopil and Volyn regions with relatively smaller volumes of gross regional product. However, they have a fairly large trade turnover with Poland due to wellestablished trade relations with Polish partners and geographical proximity to Poland.

According to the geographical structure of commodity export deliveries from Ukraine to Poland, the leaders by their volumes are the most developed Ukrainian regions (Dnipropetrovsk, Donetsk, Kyiv), accounting for more than $41 \%$ of Ukrainian exports, and Lviv, Ternopil and Volyn regions, having close historical ties with Poland (Fig. 2). In addition to it, Poland is the important commodity export market for many Ukrainian regions. So, in 2018, Poland took the 1st place among other world countries in the geographical structure of the commodity exports from Dnipropetrovsk, Lviv, Rivne and Ternopil regions, the 2 nd place - as regards Volyn, Vinnytsia, Zhytomyr, Luhansk and Khmelnytskyi regions, the 4th - as regards Donetsk, Transcarpathian, Ivano-Frankivsk, Kherson, Chernivtsi and Chernihiv 
regions (Fig. 2). The proximity of the geographical location relative to Poland is significant for the six western Ukrainian regions (gravity factor), which account for more than $34 \%$ of Ukrainian export deliveries to Poland. In particular, the Polish share in the geographical structure of exports from Ternopil region was $49.0 \%$, from Lviv - $26.9 \%$, from Volyn - 21.1\%, from Rivne - 19.1\%, from Zhytomyr - 11.7\% in 2018 (External... 2019).

The smallest volumes of Ukrainian goods exported to Poland occur in Kirovohrad, Chernivtsi, Sumy, Kherson, Mykolaiv and Luhansk regions (Fig. 2). The share of Poland in the geographical structure of commodity exports from such Ukrainian regions as Mykolaiv, Poltava, Sumy and Kirovohrad is $1-2 \%$ of total exports.

In terms of total Polish commodity imports, the leading importers are Kyiv (1,134.2 million USD in 2018), and Ukrainian regions: Lviv (587.2 million USD), Kyiv (358.7 million USD), Dnipropetrovsk, Ternopil and Volyn. The smallest share of Polish commodity imports was noted in Kirovohrad, Kherson, Chernivtsi, Chernihiv, Mykolaiv and Luhansk regions (Fig. 3). In 2018, the share of Poland was larger in the total volume of commodity imports of such western regions as Ternopil (42.7\%), Lviv (21.7\%), Rivne (19.1\%), Chernivtsi (12.5\%), Khmelnytskyi (11.2\%) and Volyn (11.1\%). Simultaneously, the Poland's share in the total volume of imports to such areas as Mykolaiv, Donetsk, Poltava, Sumy and Kirovohrad was less than 2\% (External... 2019).

Disparity in the commodity exchange is observed among Ukrainian regions and Polish voivodeships as partners of the interregional cooperation. This reduces the opportunities for an increased utilization of the economic potential of the Ukrainian regions and leads to a number of problems when using the available capabilities of their economic complexes. Seventeen regions of Ukraine had a positive balance of commodity trade with Poland in 2018. The largest surplus (510.7 million USD) was for the Dnipropetrovsk region due to the supply of iron and manganese ore, products of the metallurgical and chemical industries and mechanical engineering to Poland. The second position was occupied by the Donetsk region (288.4 million USD), which supplied Poland with significant volumes of products from the metallurgical and chemical industries and mechanical engineering. The largest negative trade balance in commodity trade with Poland (-822.7 million USD) in 2018 was in the city of Kyiv (the main importer of Polish commodities) as well as in the Kyiv, Lviv and Sumy regions.

The estimation of the bilateral commodity trade balance coefficient $\left(K z b_{i}\right)$, in the context of the Ukrainian regions, has shown that the Volyn, Poltava, Chernihiv, Chernivtsi, Khmelnytskyi and Ternopil regions are characterized by a relatively balanced trade, however with a slight predominance of exports over imports ( $K z b_{\text {i }}$ is close to 0$)$. The balance coefficient of the Ukrainian external commodity trade with Poland reveals that the most unbalanced trade relations take place in the Donetsk, Dnipropetrovsk, Zaporizhzhia and Vinnytsia regions with a sharp predominance of exports over imports ( $K z b$, from +0.81 up to $+0.38)$. At the same time, there is an imbalance in the Ukrainian commodity trade with Poland in the city of Kyiv, and the Kyiv, Sumy and Mykolaiv regions (Fig. 4). As far as the Ukrainian regions are concerned, the balance coefficient in the trade with Poland, due to the significant negative trade balance, ranges from - 0.39 (Mykolaiv region) and up to -0.68 (Kiev region).

The connectivity coefficient (Kzv) (formula 3) of trade links between Polish and Ukrainian regions shows that thirteen Ukrainian regions have the close bilateral commodity trade connectivity, since the value of the coefficient $K z V$ is greater than 1 .

Particularly, this coefficient is higher than 1.5 in five Ukrainian regions (Fig. 5). This is mainly due to the export dependence of these regions on the commodity trade with Poland. The highest level of the trade connectivity with Poland was recorded in the Donetsk $(K z v=4.4)$, Dnipropetrovsk $(K z v=2.4)$, Luhansk $(K z v=1.9)$, Volyn $(K z v=1.9)$ and Kherson $(K z v=1.7)$ regions. This is due to the 


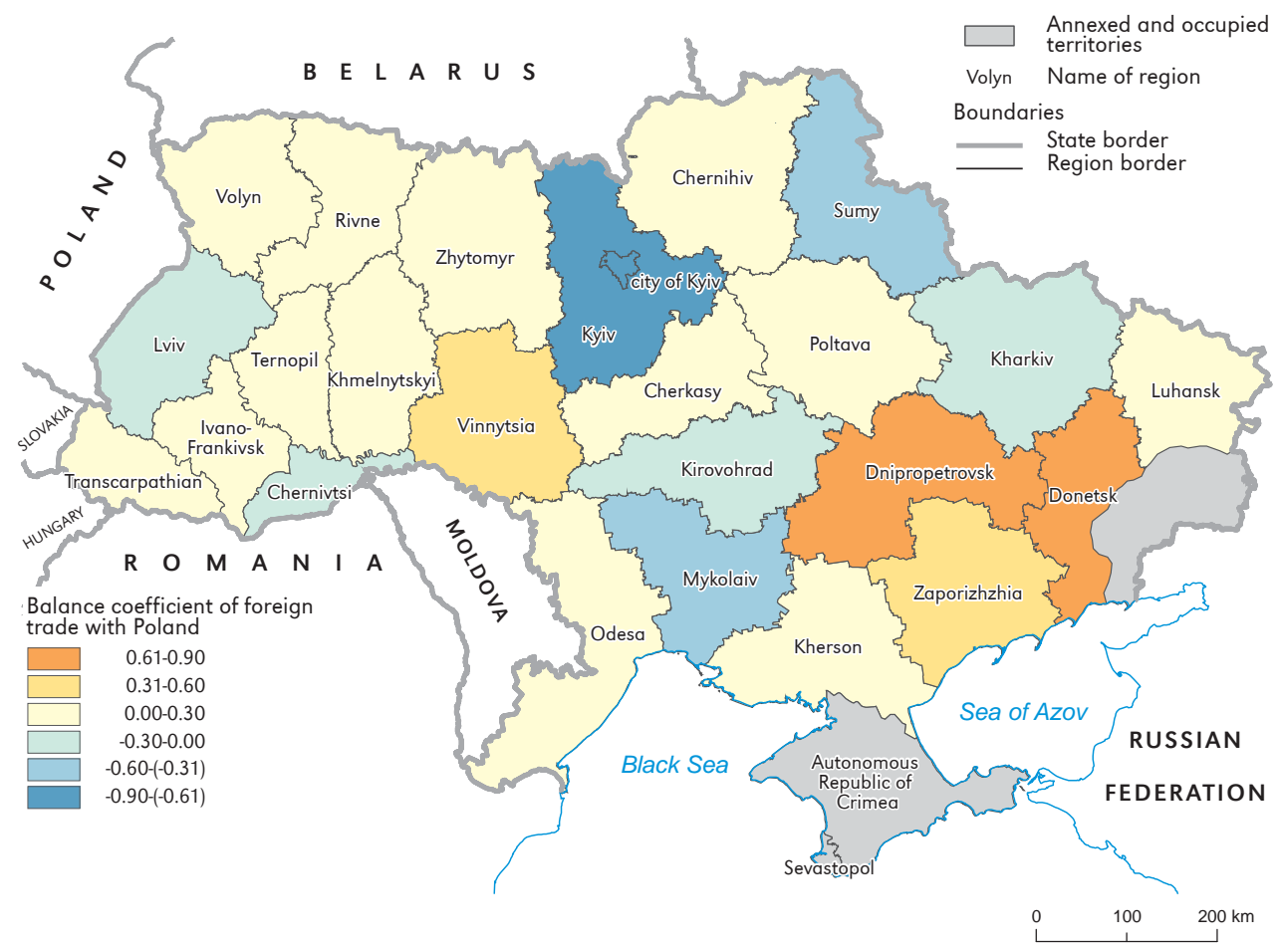

Figure 4. Spatial differentiation of the balance coefficient of foreign trade of Ukrainian regions with Poland in 2018

Source: Based on data from State Statistics Service of Ukraine (2019)

significant predominance of powerful commodity export flows from the mining, metallurgical, chemical and engineering industries from these regions over the imported commodity flows from Poland. A relatively high coefficient of commodity trade links with Poland (Kzv from 1.5 to 1.2 ) in 2018 is typical for the Ivano-Frankivsk, ZLviv, Transcarpathian, Zhytomyr, Odesa, Kirovohrad and Zaporizhzhia regions. The lowest values of the coefficient of the trade-related cooperation with Poland are registered in Mykolaiv $(K z v=0.15)$, Sumy, Chernivtsi and Kyiv regions, as well as the city of Kiev (Fig. 5). These regions are characterized by a significant import dependence on the commodity trade with the Polish voivodeships because of the unbalanced character of trade relations.

The results of the calculations of the connectivity coefficient of trade links and their comparison according to the determined criteria by use of the formulas (4-6) allowed to distinguish the types of regions of Ukraine according to the characteristics of their commodity trade with Poland. At the same time, the balance factors of commodity trade and Poland's share in the region's commodity trade were also considered. The Ukrainian regions can be divided according to the following characteristics: (1) region's dependence upon exports/imports with Poland; (2) Poland's dependence upon export/import commodity deliveries to/from the region; (3) absence of the trade dependence upon the part of the region; (4) absence of the trade dependence upon the part of Poland.

According to these criteria, the regions of Ukraine can be classified under the type of commodity trade with Poland as shown in Table 1. Those regions, whose trade with 


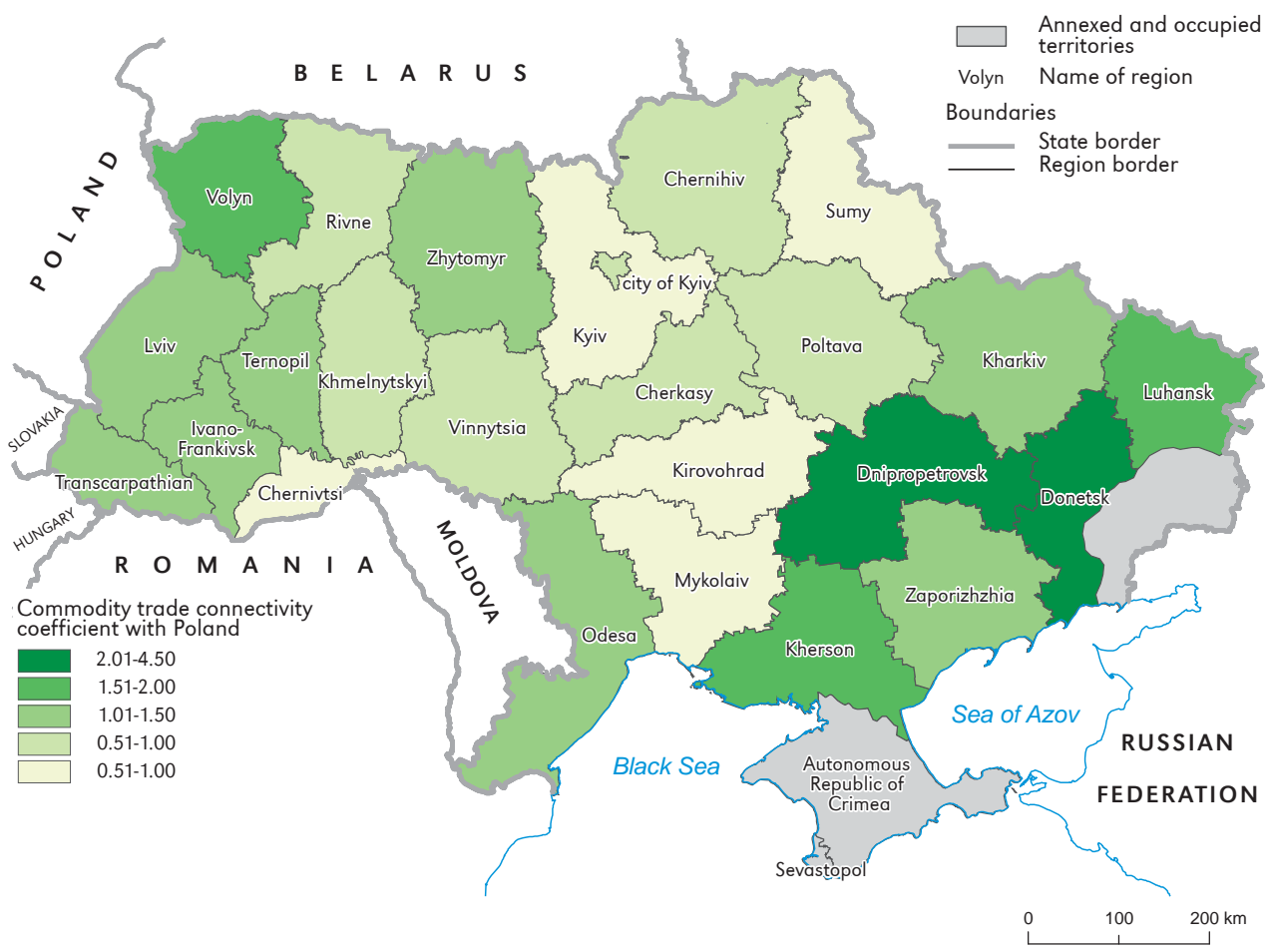

Figure 5. Spatial differentiation of the commodity trade coefficient connectivity of Ukrainian regions with Poland in 2018

Source: Based on data from State Statistics Service of Ukraine (2019).

Poland is defined by such characteristics as balance, and symmetry, are marked in bold.

A separate group consists of six regions of Ukraine that have a significant export dependence of their economies upon the trade with Poland, since the connectivity coefficient is greater than 1. At the same time, the Volyn, Rivne and Ternopil regions are highly dependent both upon the export and upon the import trade with Poland, despite the significant sustainability. Poland's share in the total turnover of these areas is very high. For example, in 2018, the share of Poland in the Ternopil region's geographical structure of exports was $49 \%$, and in the structure of imports $-42.7 \%$. A separate type is made up of Zhytomyr, Transcarpathian, IvanoFrankivsk, Zaporizhzhia, Odesa and Kherson regions $(K z v=1.2-1.7)$ which are dependent on the commodity export to Poland, with simultanious absence of dependence on the part of Poland. The Poltava, Khmelnitskyi, Cherkasy and Chernihiv regions are characterized by the absence of the significant dependence on trade with Poland, with a high level of balance where the values of connectivity of commodity trade coefficient are lower than 1.0 (Fig. 5).

Simultaneously, all the Ukrainian regions with the value of connectivity coefficient lower than 1 belong to different types, depending on the ratio of the export-import flows to Poland and the average volumes of exports and imports to all the partner-countries determined on the basis of formulas (4-6). Therefore, Kyiv, Kirovohrad, Mykolaiv, Sumy, Chernivtsi regions and the city of Kyiv (Tab. 1) have a significant dependence upon the commodity imports from Poland with a large 
Table 1. The classification of Ukrainian regions by the type of commodity trade with Poland

\begin{tabular}{|c|c|c|c|}
\hline Character of dependence & $\begin{array}{l}\text { Export-dependent } \\
\text { Regions }\end{array}$ & $\begin{array}{l}\text { Import-dependent } \\
\text { Regions }\end{array}$ & $\begin{array}{l}\text { Absence of dependence } \\
\text { on the part of the Region }\end{array}$ \\
\hline $\begin{array}{l}\text { Export dependence } \\
\text { of Poland }\end{array}$ & & $\begin{array}{l}\text { Volyn, Rivne, Ternopil } \\
\text { regions }\end{array}$ & \\
\hline $\begin{array}{l}\text { Import dependence } \\
\text { of Poland }\end{array}$ & $\begin{array}{l}\text { Dnipropetrovsk, Donetsk, } \\
\text { Luhansk, Volyn, } \\
\text { Rivne, Ternopil regions }\end{array}$ & $\begin{array}{l}\text { Lviv, Kharkiv, Vinnytsia } \\
\text { regions }\end{array}$ & \\
\hline $\begin{array}{l}\text { Absence of dependence } \\
\text { upon the part of Poland }\end{array}$ & $\begin{array}{l}\text { Zhytomyr, Transcarpathian, } \\
\text { Ivano-Frankivsk, Zapor- } \\
\text { izhzhia, Odesa, Kherson } \\
\text { regions }\end{array}$ & $\begin{array}{l}\text { Kyiv, Kirovohrad, Mykolaiv, } \\
\text { Sumy, Chernivtsi regions, } \\
\text { the city of Kyiv }\end{array}$ & $\begin{array}{l}\text { Poltava, Khmelnytsk, } \\
\text { Cherkasy, Chernihiv } \\
\text { regions }\end{array}$ \\
\hline
\end{tabular}

unbalanced trade. At the same time, the Lviv, Vinnytsia and Kharkiv regions form a separate type of regions, which are characterized by the balance commodity trade with Poland with the value of the connectivity coefficient being slightly close to 1.0 (Fig. 5).

In general, the economy of the Ukrainian regions is characterized by a relatively low degree of export dependence upon the Polish market. A pair correlation coefficient $\left(R=0.52 ; t_{s t}=2.92 ; t_{23 ; 0.05}=2.07\right)$ between the share of goods exported to Poland and the gross regional product of Ukrainian regions confirms this fact. On the contrary, a high degree of dependence of the Ukrainian region economy upon the commodity imports from Poland has been found. This is evidenced by the fact that eight regions of Ukraine have a negative trade balance in their commodity trade. The calculated coefficient of the pair correlation of the share of imports from Poland with the gross regional product of the regions $\left(R=0.84 ; t_{s t}=7.49 ; t_{23 ; 0.05}=2.07\right)$ confirms this dependence.

Thus the findings of the analysis that was carried out for the purpose of grouping of the Ukrainian regions by the commodity trade type have shown that the majority of the Ukrainian regions are primarily the suppliers of raw materials to Poland, thereby being dependent upon the imports of predominantly high-tech industrial products from Poland. A significant asymmetry of trade links of Ukrainian regions with Polish voivodeshipsis is present. A comparison of the balance coefficients with the trade connectivity coefficients indicates the dependence of the commodity markets of industrially developed regions of Ukraine upon the commodity export deliveries to Poland. This dependence is confirmed by the calculated pair correlation coefficient between these two coefficients $\left(R=0.75 ; t_{s t}=5.38 ; t_{23 ; 0.05}=2.07\right)$. At the same time, for regions that have a low level of industrial development and specialize in the production of agricultural goods, there is a significant import dependence upon the commodity flows of Polish high-tech products. In general, trade between Ukraine and Poland is more important for Ukraine and most of its regions than for Poland, due to the fact that Poland has a more diversified geographical and commodity structure of its external trade.

\section{Conclusion}

The main goal of the study was to identify the features of the regional differentiation of commodity trade between the Ukrainian regions and Poland. It has been established that, in terms of the spatial aspect, the commodity trade of Ukrainian regions with Poland is markedly differentiated. Wide disparities in the development of the UkrainianPolish interregional cooperation are primarily reflected in the asymmetry of the bilateral external trade parameters. The most economically developed regions and western regions of Ukraine are actively involved in the trade exchange. In particular, the western regions 
of Ukraine have close trade ties with Polish partners due to their geographical proximity to Poland and due to the cross-border cooperation within the framework of the Carpathian Euroregion and the Euroregion "Bug".

The regional differentiation of Ukraine's commodity trade with Poland is clearly a reflection of the effect of $W$. Tobler's first law of geography, "Everything is related to everything else, but near things are more related than distant things" (Tobler 1970). The western regions of Ukraine, which directly border Poland, are distinguished by strong exports and imports and have high coefficients of trade connectivity. This is facilitated by their proximity to Poland, the advantages of the border geographical location, the presence of an extensive network of roads and railways, which provide export-import transportation and have the transit value for the territories of these regions.

The foreign trade relations between the regions of Ukraine and Poland are significantly influenced by transport routes connecting the two countries. This is confirmed by the fact that the pair wise correlation coefficient between the volume of exports of goods and the volume of road transport of goods is $0.67\left(t_{s t}=4.37 ; t_{23}\right.$; $0.05=2.07$ ), and between the export of goods and the length of railways $-0.59\left(_{\text {tst }}=3.46\right.$; $t_{23}$; $0.05=2.07$ ). Accordingly, the import of goods from Poland to the regions of Ukraine and the total turnover are significantly affected by the turnover of road transport (correlation coefficient is, respectively, $0.84\left(t_{s t}=7.48 ; t_{23 ; 0.05}=2.07\right)$ and $\left.0.80\left(t_{s t}=6.29 ; t_{23 ; 0.05}=2.07\right)\right)$. Thus, in commodity trade between the two countries, road transport is of paramount importance for movement of a significant amount of consumer goods, whereas rail transport specializes in the transportation of heavy goods (iron ore, coal, ferrous metals, construction materials, etc.).

The extensive cross-border transport network connecting Poland and Ukraine, which consists of routes (among them of major importance are E40, E372, E373, M07, M09, M10 and M11) and railways (6 railway checkpoints) facilitates the development of trade relations. There are 11 checkpoints on the PolishUkrainian border: 5 automobile checkpoints
(Korczowa-Krakovets, Krościenko-Smilnytsya, Medyka-Shehyni, Budomierz-Hrushev, Przemyśl-Usty-luh), 4 railway checkpoints (Hrubieszów-Volodymyr-Volynskyi, Krościenko-Khyriv, Przemyśl-Mostyska, Werchrata-Rava-Ruska), and 2 automobile and railway checkpoints (Dorohusk-Yahodyn, Hrebenne-Rava-Ruska). Ukraine and Poland are united by international transport corridors: Pan-European No. 3 (Cretan No. 3), Europe-Asia (TRACECA), Gdańsk-Odesa (Baltic Sea-Black Sea).

The connectivity coefficient $(K z v)$ calculated for bilateral commodity flows shows that a high level of dependence upon the commodity trade with Poland is typical for 6 regions of Ukraine, while Ukraine, in general, has a relatively high level of dependence on trade with Poland ( $K z v=1.46$ ) (Matveeva, 2007). The assessment indicator of the commodity trade balance in the context of Ukrainian regions has confirmed the fact that the Ukrainian external commodity trade with Poland tends to be balanced in regions with an average level of economic development. At the same time, highly developed regions of Ukraine have an unbalanced commodity trade due to the dominance of exports of raw materials to Poland. The raw material orientation of Ukraine's external trade with Poland deepens structural deformations of the industrial complex at the regional level. Therefore, any cooperation in the field of the fourth and the highest technological modes is the basis of the regional integration within the framework of the Ukraine's European integration strategy and its implementation.

There is a similar significant asymmetry in the bilateral Ukrainian-Polish commodity trade, since Poland does not have a significant dependence on the trade with Ukraine, because of its major focus on the EU and highly developed world countries.

The asymmetry of bilateral trade relations between the regions of Ukraine and Poland is manifested in the fact that the border regions of both countries are the most involved in the exchange of goods. Thus, Komornicki analyzed the role of commodity trade in the local development of Polish regions and found 
that Lublin and Podkarpackie voivodeships are leaders in Polish exports to neighbouring western regions of Ukraine (Komornicki, 2010). At the beginning of the 21st century, Polish regions' trade with Ukraine developed within two transport and communication axes: in the latitudinal direction from the border to Krakow and in the north-western direction from the border with Ukraine via Lublin to Warsaw. The city of Lublin had the strongest ties with Ukrainian partners. Komornicki also found that by 2007 there was an increase in the concentration of exports of goods to Ukraine in the Masovian, Silesian, Greater Poland and Lower Silesian voivodeships (Komornicki, 2010).

Disproportions in trade turnover among Ukrainian regions and Polish voivodeships are major barrier that hinder to exploit the full economic potential of many Ukrainian regions and create a number of problems associated with the efficient use of existing natural, industrial and labour resources. At the same time, Ukraine has a strong export dependence on the supply of goods to the Polish market, since Poland is one of the main trading partners of Ukraine. Therefore, Ukraine is interested in increasing share of external trade links with Poland, including the regional level.

Since the economic situation in Ukraine has been highly complicated in recent years, one of the ways to improve it may be the coordination activities of Ukraine and Poland to diversify commodity supplies. In addition, it is necessary to deepen the cooperation in the development of individual industries and agriculture, and the transport infrastructure modernization. Ukraine and Poland do not sufficiently use the opportunities for increased inter-regional cooperation, relying on the economic and natural potentials of the regions of both countries, which is due, primarily, to the limited financial resources and the difficult economic situation in the Ukrainian economy in the context of the conflict in the East of Ukraine. It is advisable to intensify interregional ties and economic cooperation between companies and enterprises of both countries, which will lead to an increase in the external trade flows. The Ukrainian border regions are also making little use of the opportunities for the cross-border cooperation within the framework of the Carpathian Euroregion and the Euroregion "Bug".

\section{Acknowledgements}

This research has been carried out within the framework of the state budget scientific theme of the Department of International Relations and Regional Studies of Lesia Ukrainka Eastern European National University called "Ukraine in the System of the European Integration and the Cross-Border Cooperation". Prospects for further researches are related to the analysis of trade links among the regions of Ukraine and Poland applying gravity models.

\section{Editors' note:}

Unless otherwise stated, the sources of tables and figures are the authors', on the basis of their own research.

\section{References}

Agreement between the Government of Ukraine and the Government of the Republic of Poland on Trade and Economic Cooperation of 04.10.1991, (1991). Retrieved from http://zakon4.rada.gov.ua/laws/show/616_019/ [24 December 2019].

Agreement between Ukraine and the Republic of Poland on Neighbourhood, Trade and Economic Cooperation. (1992). Retrieved from https://zakon.rada.gov.ua/laws/show/616_172 [24 December 2019]. 
Aguirre, I. (1999). Making sense of paradiplomacy? An intertextual enquiry about a concept in search of a definition. Regional and Federal Studies, 9(1), 185-209.

https://doi.org./10.1080/13597569908421078

Aleksiievets, L., Aleksiievets, M., Ilchuk, I. (2015). Tendenciï ta problemi spivvracì Ukraïni ì Pol'ŝ̀̀ $v$ ekonomičnij sferì u sučasnih umovah (Trends and problems of cooperation between Ukraine and Poland in the economic sphere in the current conditions). Naukovi zapysky Ternopilskoho natsionalnoho pedahohichnoho universytetu imeni Volodymyra Hnatiuka. Seriia: Istoriia, 2(4), 122-130. [Ukrainian]

Ambroziak, Ł., Błaszczuk-Zawiła, M. (2016). Czy unijne preferencje handlowe maja znaczenie? Przypadek polsko-ukraińskiej wymiany handlowej w latach 2010-2015. Zeszyty-naukowe Uczelni Vistula. Ekonomia XI. Stan i rozwój bilateralnej współpracy gospodarczej Polski i Ukrainy, 47(2), 19-33.Warszawa: Instytut Badań Rynku, Konsumpcji i Koniunktur.

Anderson, J., Wincoop, E. (2003). Gravity with gravitas: A solution to the border puzzle. American Economic Review, 93(1), 170-192. https://doi.org/10.3386/w8079

Area Bodies of State Statistics. (2019). State Statistics Service of Ukraine: Official site. Retrieved from http://www.ukrstat.gov.ua/

Babets, I.H., Borshchevsky, V.V., Mihushchenko,Yu.V. (2011). Ways of development of interregional Ukrainian-Polish cooperation. Retrieved from Iv.niss.gov.ua/public/File/1/ Babets.pdf [19 December 2019]. [Ukrainian]

Baluk, W. (2018). Formalny i materialny wymiar partnerstwa strategicznego Polski i Ukrainy. Sprawy Międzynarodowe, 1, 109-137.

Borshchevsky, V. (2007). Ukraïns'ko-pol's'ke ekonomične spivrobìtnictvo v umovah êvroìntegraciï: monografiâ (Ukrainian-Polish economic cooperation in the condition of European integration). Lviv: Avers. [Ukrainian]

Borshchevsky, V.V. (2009). Optimization of Ukraine and Poland economic cooperation in the process of Ukraine approaching to EU. [Manuscript]. Kyiv National University. Retrieved from http://irbis-nbuv.gov.ua/cgi-bin/irbis_nbuv/cgiirbis_64.exe?C21COM [20 December 2019]. [Ukrainian]

Chorna, N. (2016). Ukraïns'ko-pol's'ke ekonomične spivrobitnictvo (Ukrainian-Polish economic cooperation). Zovnishnia torhivlia: ekonomika, finansy, pravo, 2, 31-41. [Ukrainian]

Coe, N.M. (2012). Geographies of production II: A global production networks A-Z. Progress in Human Geography, 36(3), 389-402. https://doi.org/10.1177/0309132511402784

Coe, N.M., Dicken, P., Hess, M. (2008). Global production networks: Realizing the potential. Journal of Economic Geography, 8(3), 271-295. https://doi.org/10.1093/jeg/lbn002

Dicken, P. (2015). Global shift: Mapping the changing contours of the world economy. Seventh Edition. New York - London: The Guilford Press.

Dicken, P., Kelly, P.F., Olds, K., Yeung, H.W.-C. (2001). Chains and networks, territories and scales: Towards a relational framework for analyzing the global economy. Global Networks, 1(2), 89-112. https://doi.org/10.1111/1471-0374.00007

Dickson, F. (2014). The internationalization of regions: Paradiplomacy or multi-level governance? Geography Compass, 8(10), 689-700. https://doi.org./10.111/gec3.12152

Duhiienko, N.O., Shevchuk, V.S. (2017). Sučasnij stan ukraïns'ko-pol's'kogo spivvrobitnictva u sferì torgìvì ta investicij (Current status of Ukrainian-Polish cooperation in trade and investment). Visnyk Zaporizkoho natsionalnoho universytetu. Ekonomichni nauky, 3(35), 86-92. [Ukrainian]

External economic activity. (2019). State Statistics Service of Ukraine: Official site. Retrieved from http://www.ukrstat.gov.ua [25 December 2019]. [Ukrainian]

Fujita, M., Krugman, P., Venables, A.J. (1999). The spatial economy: Cities, regions and international trade. Cambridge: MIT Press. 
Hummels, D., Rapoport, D., Yi, K.M. (1998). Vertical specialization and the changing nature of world trade. Economic Policy Review, 4(2), 79-99.

Jakimowicz, R. (2004). Wybrane aspekty polityczne i gospodarcze stosunków polsko-ukraińskich w dobie integracji europejskiej (lata 1991-2002). In M. Bankowicz, K. Szczerski (Eds.). Europa 25. Opinie środowiska akademickiego Krakowa na temat politycznych wyzwań poszerzonej Unii Europejskiej (pp. 253-280). Kraków: Szkoła Wyższa im. Bogdana Jańskiego Wydział Zamiejscowy.

Kalita, V. (2007). Ukraïna v pol's'kij zovnišnij torgivlì (Ukraine in the Polish foreign trade). Regional'na ekonomika, 1, 282-289. [Ukrainian]

Kalita, W., Puchalska, K., Barwińska-Małajowicz, A. (2008). Ocena polsko-ukraińskiej wymiany handlowej z uwzględnieniem obszarów transgranicznych. In M.G. Woźniak (Eds.), Spójność społeczno-ekonomiczna a modernizacja regionów transgranicznych (pp. 83-94). Rzeszów: Wydawnictwo Uniwersytetu Rzeszowskiego.

Kaplinsky, R., Morris, M. (2003). Handbook for value chain research. Vol. 113. Brighton: University of Sussex, Institute of Development Studies. Retrieved from https://www.ids.ac.uk/ids/global/pdfs/VchNov01.pdf

Komornicki, T. (2009a). Assessment of regional economic hazard based on export statistics. In J. Kitowski (Ed.). Countries of Central and Eastern Europe versus global economic crisis. Geopolitical Studies, 15, (pp. 165-182). Rzeszów: Uniwersytet Rzeszowski, Instytut Geografii i Przestrzennego Zagospodarowania im. S. Leszczyckiego PAN.

Komornicki, T. (2009b). Ocena charakteru, struktury i intensywności polskiego eksportu w kontekście celów polityki regionalnej, na poziomie województw. Ekspertyza dla Ministerstwa Rozwoju Regionalnego. (Typescript). Warszawa.

Komornicki, T. (2010). Rola wymiany towarowej ze wschodnimi sąsiadami Polski w gospodarce lokalnej. In Z. Zioło, T. Rachwał (Eds.). Procesy transformacji przemysłu w regionalnych i krajowych układach przestrzennych (pp. 105-116). Prace Komisji Geografii Przemysłu Polskiego Towarzystwa Geograficznego, 15. Warszawa-Kraków: Wydawnictwo Naukowe UP.

Korchun, V.S. (2013). Zovnišn'otorgovel'nì vìdnosini Pol'ŝ̀ ta Ukraïni (Foreign trade relations of Poland and Ukraine). Ukraïna ta Pol'ŝa: minule, s'ogodennâ, perspektivi, 2, 57-62. [Ukrainian]

Krugman, P.R. (1991). Geography and trade. Cambridge: MIT Press.

Linetsky, A.F., Tarasov, A.G., Kovalev, V.E. (2017). Rol' regionov vo vneshnetorgovoy deyatel'nosti Rossii $\checkmark$ usloviyakh novykh geopoliticheskikh vyzovov (Role of regions in the foreign trade activity of Russia in the context of new geopolitical challenges). Ekonomika regiona, 13(3), 827-838.

https://doi.org./10.17059/2017-3-15 [Russian]

Mahutga, M.C. (2014). Global models of networked organization, the positional power of nations and economic development. Review of International Political Economy, 21(1), 157-194. https://doi.org/10.1080/09692290.2013.779932

Makar, Yu. (2016). Współczesne stosunki ukraińsko-polskie w kontekście procesów integracji europejskiej. Wshód Europy, 2(2), 169-181.

Martynova, L.B., Chorna, N.M. (2018). Trade and economic cooperation between of Ukraine and Poland under development of integration processes in Europe. Infrastruktura Rynku, 21, 17-21. [Ukrainian]

Matveeva, V. (2007). Deâki aspekti zovnišn'oï torgivli Ukraïni v kontekstì êvroìntegraciï (Some aspects of Ukraine's foreign trade in the context of European integration). Zhurnal ievropeiskoi ekonomiky, September, 6(3), 280-293. [Ukrainian]

Mazaraki, A.A., Melnyk, T.M. (2010). Dvostoronnê spivrobitnictvo Ukraïni ta Pol'šì: stan ta možlivostì aktivizacii (Bilateral cooperation between Ukraine and Poland: the state and possibilities of activation). Formuvannia rynkovykh vidnosyn v Ukraini, 12, 257-266. [Ukrainian]

McCallum, J. (1995). National borders matter: Canada-U.S. regional trade patterns. American Economic Review, 85(3), 615-623. 
Musiałowicz, B. (2017). Wymiana handlowa towarami pomiędzy Polska i Ukraina odnotowała znaczny wzrost w porównaniu do roku 2015. Retrieved from https://ukraine.trade.gov.pl/pl/ukraina/wymiana-handlowa/238234,wymiana-handlowa-z-ukraina-w-2016-r-html [27 December 2019].

Ocena sytuacji w handlu zagranicznym w 2018 roku (na podstawie danych wstępnych GUS). Retrieved from https://www.gov.pl/attachment/112bf04c-f46c-44d8-a57a-e83a99a4f093 [25 December 2019].

Osadcha, N.V., Petrova, A.Ye. (2017). Pol'ŝa âk strategičnij zovnišn'otorgovel'nij partner Ukraïni z pozicij bezpeki zovnišn'oï torgivlì (Poland as a strategic foreign trade partner of Ukraine from the standpoint of security foreign trade). Ekonomichnyi visnyk Donbasu, 1(47), 25-30. [Ukrainian]

Parrilli, M.D., Nadvi, K., Yeung, H.W-C. (2013). Local and regional development in global value chains, production networks and innovation networks: A comparative review and the challenges for future research. European Planning Studies, 21(7), 967-988. https://doi.org/10.1080/09654313.2013.733849

Peck, J., Yeung, H.W.-c. (2003). Remaking the global economy: Economic-geographical perspectives. London: SAGE. https://doi.org/10.4135/9781446216767

Poland. Information on the activities of the Ukrainian-Polish Intergovernmental Commission on Economic Cooperation. Ministry for Development of Economy, Trade and Agriculture of Ukraine: Official site. (2019). Retrieved from http://www.me.gov.ua/Documents/Detail?lang=uk-UA\&id=3fd1900168a0-4aa6-8cc3-5a7676764fc0\&title=Polscha [26 December 2019].

Popova, Yu.M., Radchenko, L.M., Yakushenko, A.S. (2016). Mižregìonal'ne spivrobitnictvo Ukraïni ta Respubliki Pol'ŝa u konteksti ìntegraciï Ukraïni do ÊS (Interregional cooperation between Ukraine and the Republic of Poland in the context of Ukraine's integration in to the EU). Ekonomichnyi prostir, 106, 36-44. [Ukrainian]

Porter, M.E. (1998). The competitive advantage of nations, 2nd ed. New York: Free Press.

Powęska, H. (2016). Handel przygraniczny w warunkach zmian przenikalności granicy. Warszawa: Wydawnictwo SGGW.

Raboszuk, A., Szymańska, K. (2016). State and perspectives of foreign trade between Poland and Ukraine. Zeszyty-naukowe Uczelni Vistula. 47(2). Stan i rozwój bilateralnej współpracy gospodarczej Polski i Ukrainy, 254-268.

Royles, E. (2017). Sub-state diplomacy: Understanding the international opportunity structures. Regional and Federal Studies, 8(10), 393-416. https://doi.org./10.1080/13597566.2017.1324851

State Statistics Service of Ukraine: Official site. (2019). Retrieved from http://www.ukrstat.gov.ua [24 December 2019]. [Ukrainian]

Szejgiec, B., Komornicki, T. (2015). Spatial differentiation of Polish export linkages. Geographia Polonica, 88(1), 173-178. https://doi.org/10.7163/gpol.0011

Tinbergen, J. (1962). Shaping the world economy: Suggestions for an international economic policy. New York: Twentieth Century Fund.

Tobler, W. (1970). A computer movie simulating urban growth in the Detroit Region. Economic Geography, 46(2), 234-240.

Vaniushkin, A.S. (2004). Vyâvlenie problem râzvitia do sozdaniâ integracionnych ob'edinenij (Identification of development problems before the creation of integration associations). Kultura narodov Prychernomoria, 56(1), 97-100. [Russian]

Wosiek, M., Kata, R. (2019). Handel na pograniczu polsko-ukraińskim: wybrane aspekty ekonomiczne. Wiadomości Statystyczne, 64(2), 44-63.

Współpraca handlowo-gospodarcza pomiędzy Ukrainq a Rzeczpospolita Polska. Ambasada Ukrainy w Rzeczypospolitej Polskiej. (2020). Retrieved from http://poland.old.mfa.gov.ua/pl/ukraine-pl/trade [24 January 2020].

Zelich, V.V., Titarenko, S.O. (2016). Sučasnì realiï ekonomičnogo rozvitku ta spìvrobitnictva miž Ukraïnoû ta Pol'ŝeû. (Modern realities of economic development and cooperation between Ukraine and Poland). 
Naukovyi visnyk Khersonskoho derzhavnoho universytetu. Seriia: Ekonomichni nauky, 17(1), 35-38. [Ukrainian]

Zhiryaeva, E.V. (2016). Analiz faktorov, vliyayushchikh na uchastie subnatsional'nykh edinits raznykh stran vo vneshneekonomiceskikh svyazyakh (The Analysis of the Factors Which Influence on the Subnational Units of Different Countries Participation in the Foreign Economic Relations). Upravlencheskoe konsul'tirovanie, 4(88), 125-135. [Russian] 